\title{
Self-eating in beavers - trophic opportunism or reaction on stress? Extreme case from Mongolia
}

\author{
Alexander P. Saveljev*, Niamosor Batbayar, Shaariybuu Boldbaatar \\ \& Batseren Dashbiamba
}

\begin{abstract}
For the purpose of preservation of a unique gene pool of autochthonous beavers Castor fiber birulai in 1985-2002 daughter population in adjoining regions of NW Mongolia and South Tuva (Tes River / Tesijn gol basin) has been introduced (Stubbe et al., 2005). Today this local population has reached 150 animals (Saveljev et al., 2015). The physical condition of the beavers that were caught by a sort of natural "ecological trap" late February, 2015 is described. As the result of extreme frosts animals have been blocked by frazil in the lodge and had no access to forage. Local people have released five animals from this ice captivity. All beavers had gnawed tails. Absence in this area of terrestrial large predators allows to assume with high degree of confidence that the reason of traumas at animals was self- (or allo-) gnawing. The facts of placentophagy and piscivory of beavers and infestation by opisthorchosis as well, as cases of predation and scavenging among mammals (the "obligate" phytophages) are discussed.
\end{abstract}

KEY WORDS: Castor fiber birulai, Mongolia, ecological traps, frazil, stress, self-gnawing.

Alexander P. Saveljev [saveljev.vniioz@mail.ru], Russian Research Institute of Game Management and Fur Farming, Preobrazhenskaya str. 79, Kirov 610000, Russia; Niamosor Batbayar, Administration of Tes sum, Zavkhan aymag, Mongolia; Shaariybuu Boldbaatar and Batseren Dashbiamba, Ministry of Environment and Green Development of Mongolia, Tes sum, Zavhan aymag, Mongolia.

* - corresponding author

\section{Самопогрызание у бобров - трофический оппортунизм или реакция на стресс? Экстремальный случай из Монголии}

\author{
А.П. Савельев*, Н.Батбаяр, Ш. Болдбаатар, Б. Дашбямба
}

РЕЗЮМЕ. С целью сохранения уникального генофонда автохтонных бобров Castor fiber birulai в 1985-2002 гг. была создана дочерняя популяция в бессточном бассейне реки Тэс в приграничных районах северо-западной Монголии и южной Тувы (Stubbe et al., 2005). Современная численность локальной популяции достигла 150 особей (Saveljev et al., 2015). После длительных морозов в последние дни февраля 2015 г. в одном из поселений звери были блокированы наледью в своей хатке и не имели доступа к кормам. Местные жители освободили пять зверей из ледового плена. Описывается физическое состояние бобров, попавших в экологическую ловушку. Все бобры имели обгрызенные хвосты. Отсутствие в этом районе крупных наземных хищников позволяет с высокой степенью уверенности предположить, что причиной необычных травм было само- или аллопогрызание. Данный феномен обсуждается в свете известных фактов поедания бобрами послеродового последа, рыбы и инвазированности их описторхисами, а также случаев хищничества и трупоедения среди млекопитающих, традиционно считающихся «облигатными » фитофагами.

КЛЮЧЕВЫЕ СЛОВА: Castor fiber birulai, Монголия, экологические ловушки, наледи, стресс, самопогрызание.

\section{Introduction}

The ecosystem of the Uvs Nuur Hollow is in the adjacent territories of Mongolia and Tuva Republic (Russia) and is, according to an apt expression of Bugrovskii (1990), a typical "zone of life concentration" in the arid belt of Eurasia. This unique region was included in the UNESCO World Heritage List (UNESCO, 2003). The Tes River (Tesiyn Gol in Mongo- lian, or Tes-Khem in Tuvinian) is the largest river in this hollow with the catchment area of $33,400 \mathrm{~km}^{2}$ and the length of $568 \mathrm{~km}$ (865 km with meandering sections).

The daughter population of beavers was established in the Uvs Nuur Hollow as a part of international program aimed on conservation of the Central Asian subspecies of beavers. Three introductions were made in 1985, 1988, and 2002 and 10, 19, and 8 animals were 


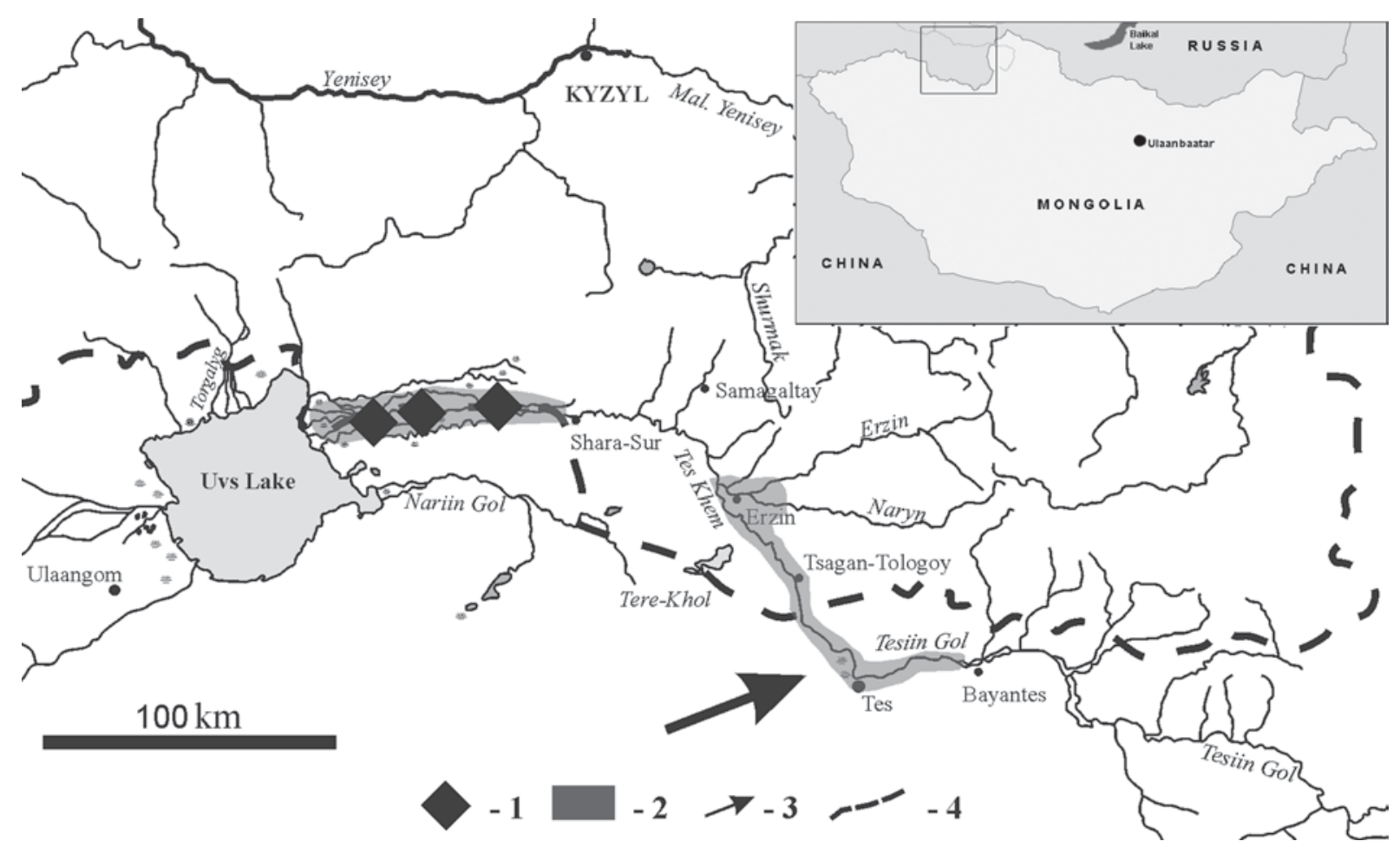

Fig. 1. Distribution of beaver C. f. birulai in Tes River watershed. 1 - sites of introduction 1985, 1988, and 2002; 2 modern distribution; 3 - location of the beaver family which have got to an ecological trap; 4 - Mongolia-Russia state border. From Saveljev et al., 2015 with changes.

released, respectively (Stubbe et al., 2005). Animals from an autochthonous population in the Bulgan River (Hovd aimag, Western Mongolia) were used as breeding material. The introduced animals belong to the Sino-Mongolian subspecies of Eurasian beaver Castor fiber birulai Serebrennikov, 1929. The releases were conducted in the lower reaches of the Tes River (Fig. $1)$. The Tes population is subdivided into two groups. The lower subpopulation inhabits the channel of the Tes River, Dund Gol and Khosht-Ergiyn Gol tributaries, and numerous large floodplain oxbows from the Shara-Sur frontier post (state border) to the near lake part of the delta overgrown with reed. This group includes not less than 12 colonies with up to 60 animals. The range of the second, upper, subpopulation extends from Erzin kozhuun (Erzin River mouth) upstream to Bayantes (Bayan-Ula) somon of Zavhan aimag. Solitary animals (weak colonies) can migrate even at the boundary between Huvsgul and Zavhan aimags. The group contains approximately 20 constant settlements most of which are large. The upper group comprises not less than 80 animals. Beavers usually live not in the main river channel but in ice-free branches. When building dams (sometimes cascades of dams), beavers create ideal habitat conditions for themselves (Fig. 2). According to the data of our interviews (Saveljev et al., 2015), cattle breeders in the Tes valley watch the living activity of new settlers with interest and have no concerns about their presence. There were no cases of poaching so far. This population of $C$. f. birulai is under protection of Mongolian Red Data Book (Boldbaatar \& Namshir, 2003; Samiya, 2013).

Short characteristic of climate and weather conditions (winter 2015)

We have received the meteorological data from the nearest monitoring station in Erzin, Tuva Republic (http:/ /www.pogodaiklimat.ru/weather.php?id=36307).

The mean annual temperature at different sites of the Uvs Nuur Hollow varies from $-2.8^{\circ} \mathrm{C}$ to $-4.3^{\circ} \mathrm{C}$. Winter temperatures can fall to $-58^{\circ} \mathrm{C}$. The values of the mean annual precipitation range are from 123 to $218 \mathrm{~mm}$, and maximum of precipitation occurs in summer. In winter, the amount of precipitation in the lake environs does not exceed 20-30 mm (see Saveljev et al., 2015; Saveljev \& Archimayeva, 2015).

Autumn 2014 was characterized by extremely low precipitation. The river appeared frozen at an unusually low water level. For the three winter months (December 1 - February 28) the temperature dropped below $-30^{\circ} \mathrm{C}$ to 14 (December), 22 (January), and 15 (February) days. The registered minimum temperature was $38.5^{\circ} \mathrm{C}$ below zero. The thickness of the snow cover did not exceed $8 \mathrm{~cm}$. By the end of the winter, frost (frazil) covered everything throughout the riverbed, especially — over beaver dams. 


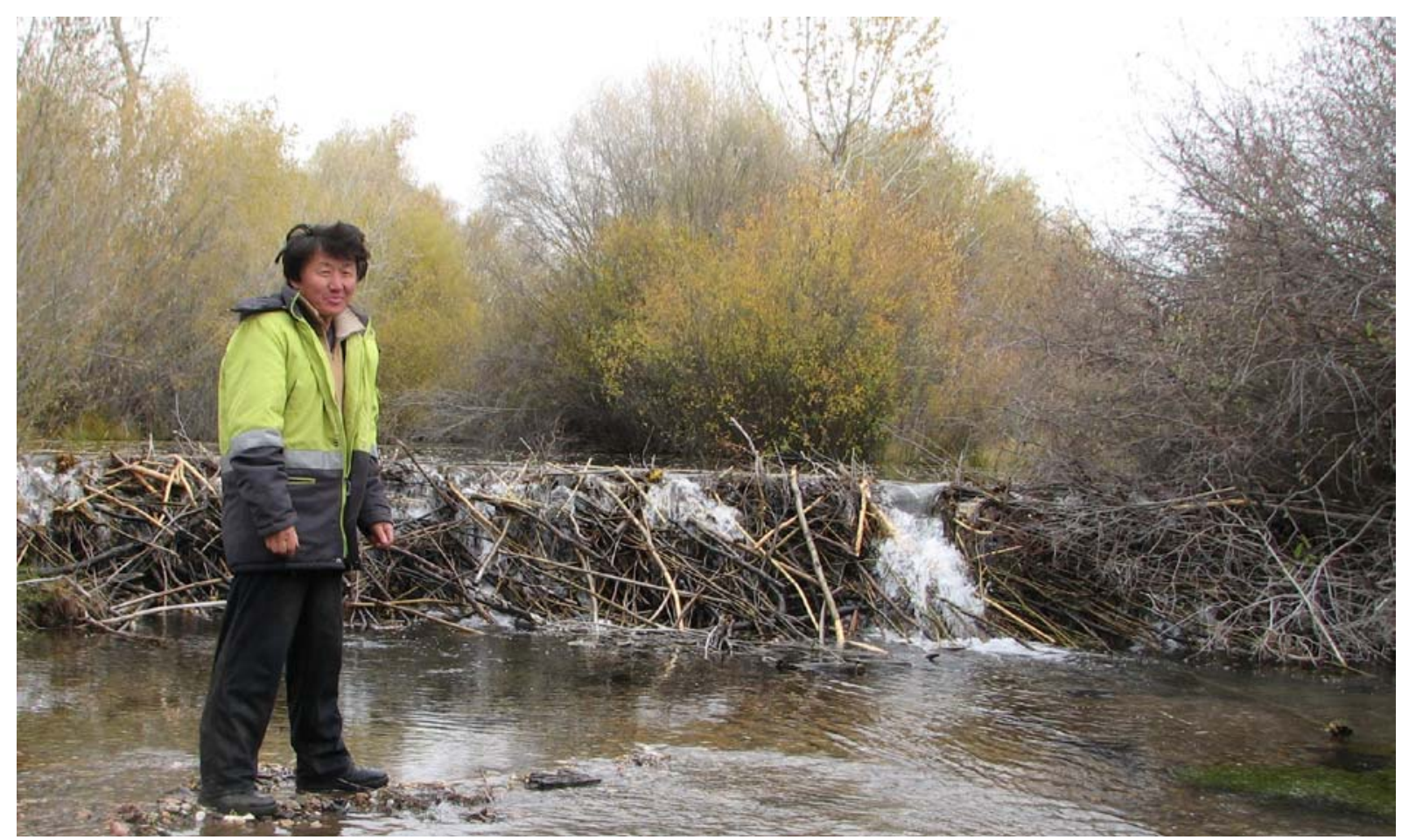

Fig.2. Beaver settlement with dam on a flow channel (oxbow) of Tes River. In the foreground one of authors - N. Batbayar. September 27, 2013. Picture by A. Saveljev.

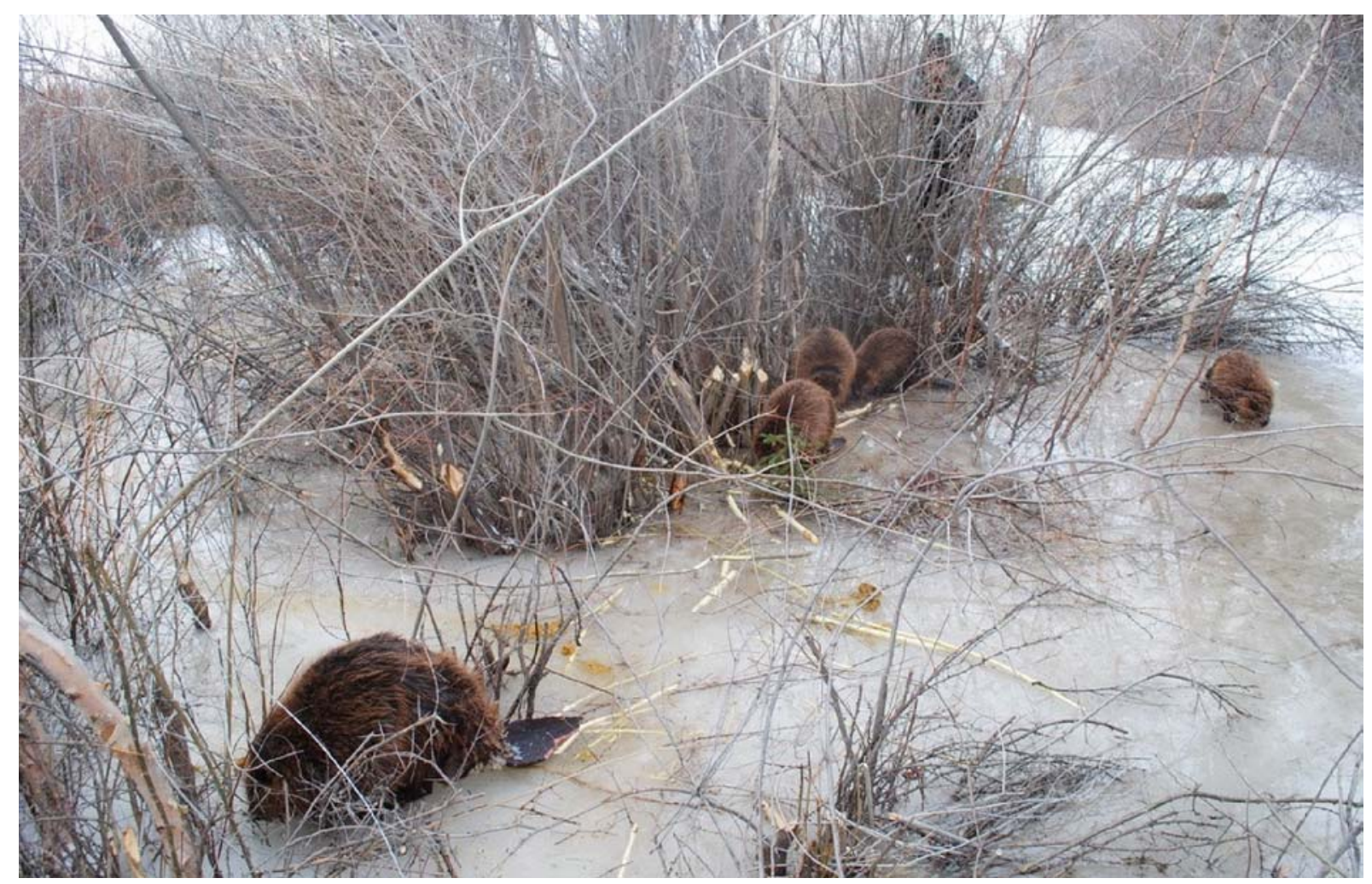

Fig. 3. Five beavers same settlement freed from ice captivity by local people. February 28, 2015. Picture by N. Batbayar. 

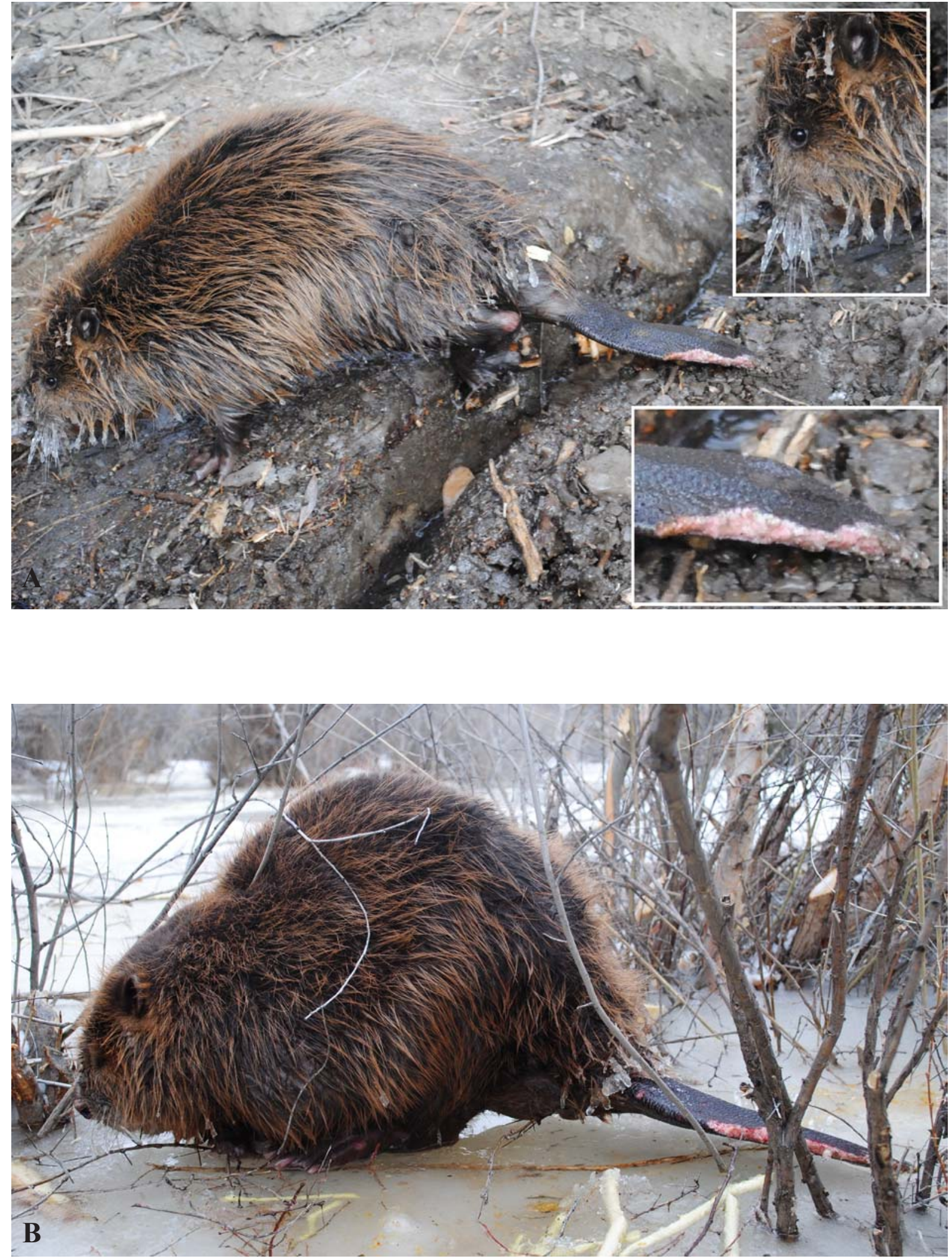

Fig. 4 A-E. Details of a physical condition of animals more close up. Pictures by N. Batbayar. 

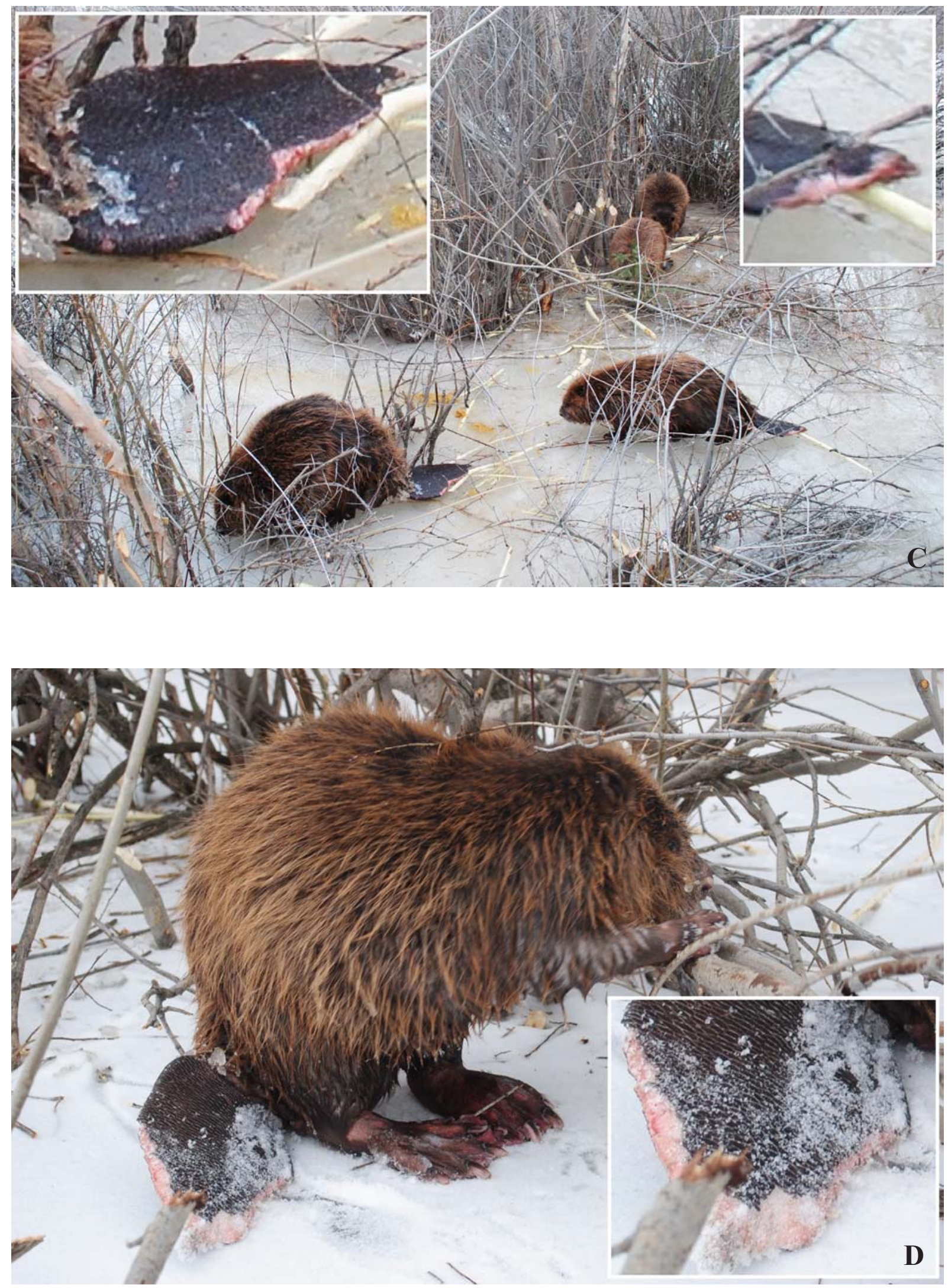

Fig. 4 A-E. Details of a physical condition of animals more close up. Pictures by N. Batbayar. 


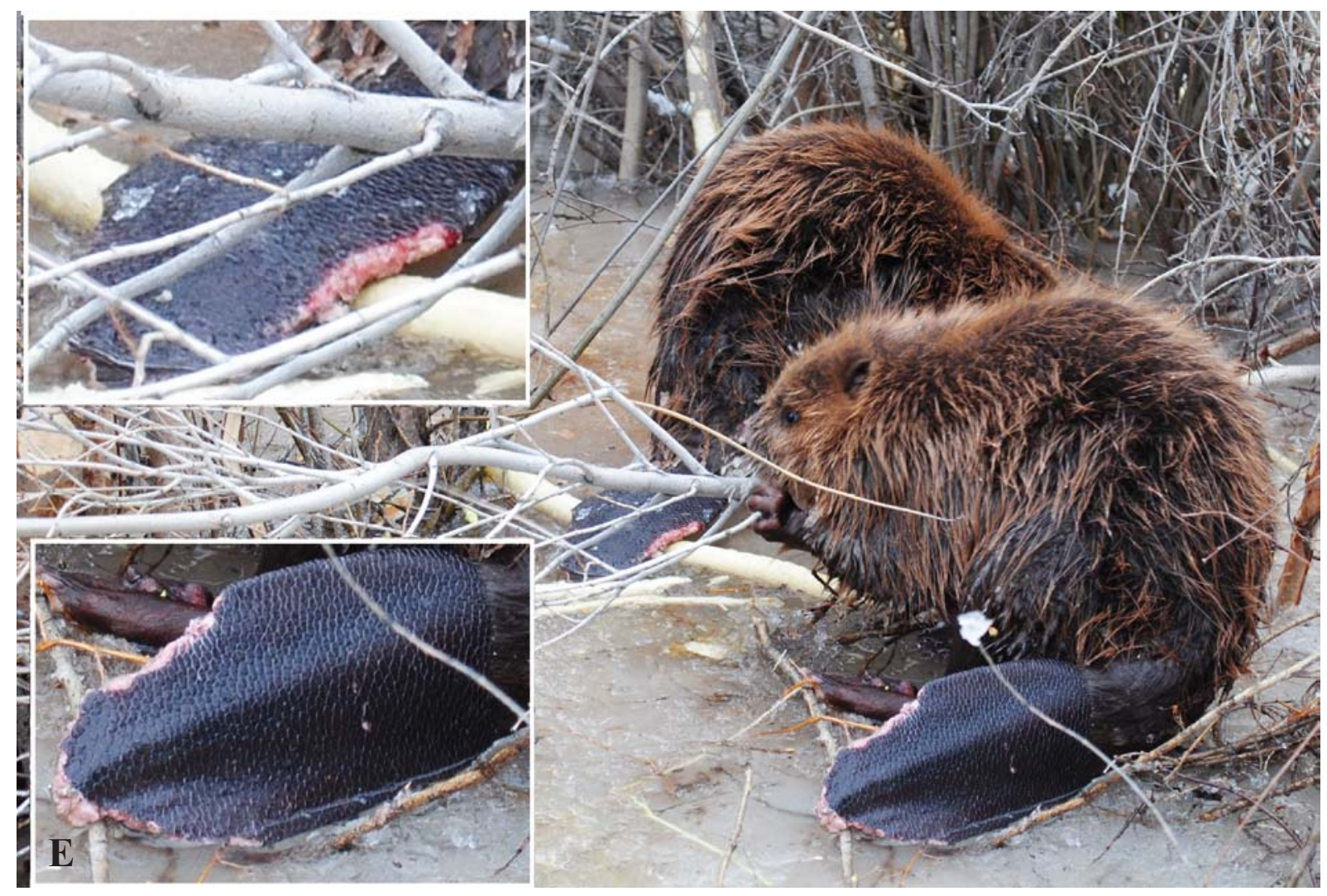

Fig. 4 A-E. Details of a physical condition of animals more close up. Pictures by N. Batbayar.

\section{Results}

Five animals lived near Tes sum village in the oxbow of Tes River (shown by an arrow in Fig. 1) in autumn 2014. One of authors (N. Batbayar) has found out one beaver who could not hide in lodge any more (that was noticed on the 28 February, 2015 in the evening). Next day the group of local residents came to this beavers' settlement and using chainsaws and other tools released a family of beavers (Fig. 3). When all the five animals went out, it was found that they all of them had their tails eaten (Figs 4A-E). No terrestrial predators were present in the area. The beavers were very thin, and immediately began to actively feed on willow branches. There is no doubt that being in such a desperate situation the animals caused such injury to themselves.

Due to severe frosts some of the animals (which were rescued from the ice captivity) died later because of hypothermia, while others - managed to survive.

\section{Discussion}

Beavers cannot be considered as obligate phytophagous rodents. For example, on Gachuurt Beaver Nursery near Ulaanbaatar City April 17, 2014 for the first time was registered eating of placentas by a female right after births of two kits. Undoubtedly, such "procedure" is usual in biology of this rodent. Direct observations of Alaskan beavers (Castor canadensis) foraging and feeding on discarded Chinook salmon (Oncorhynchus tshawytscha) carcasses were reported (Gleason et $a l ., 2005)$. High rate of opisthorchosis in beavers in the Voronezh region (Romashov, 1958) is also (but indirect) proof of "piscivory" of beavers. Similar deviations in diets have been described and for other "typical" phytophagous mammals (Clauss et al., 2016; Dorward, 2015; and others).

We can assume that beavers in the conditions of extreme scarcity of food while being locked in their lodges had no choice but to chew (eat) their tails. Other - more probable - assumption: beavers were engaged in self-, or allo-gnawing due to extreme stress. This phenomenon is known in animals kept in fur farms and zoos.

\section{Conclusions}

The dispersion of animals in peripheral parts of area, as a rule, is accompanied by "struggle" with difficult environmental conditions (Battin, 2004). Beavers have to overcome these hardships in many Siberian regions (Bentkhen et al., 1970) and Mongolia. Ecological traps, on the one hand, create complexities in con- 


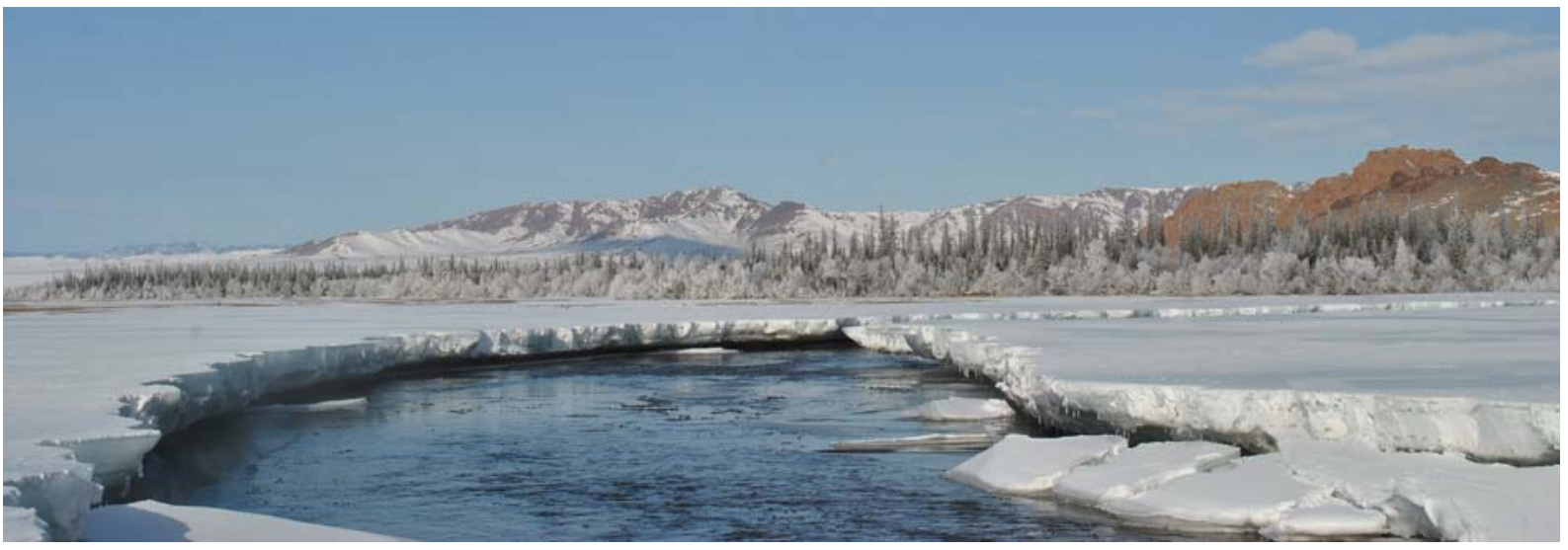

Fig. 5. The same place of Tes River four weeks later after the reported ice tragedy. Picture by N. Batbayar.

servation of rare animals. But on the other hand, extreme situations allow to discover limits of ecological plasticity of the beaver.

ACKNOWLEDGEMENTS. We would like to thank Vyacheslav Soloviev (VNIIOZ, Kirov) for technical assistance.

\section{References}

Battin J. 2004. When good animals love bad habitats: ecological traps and the conservation of animal populations // Conservation Biology. Vol.18. No.6. P.1482-1491.

Bentkhen P.V., Schvetsov Yu.G. \& Romanov G.G. 1970. [Influence of winter conditions on acclimatization and re-acclimatization of semiaquatic mammals in Eastern Siberia] // [Questions of Game Management in Siberia and the Far East]. Irkutsk. P.25-27 [in Russian].

Boldbaatar Sh. \& Namshir Z. 2003. [New place a finding of the beaver (Castor fiber), supervision on its ecology and habits] // [Mammalogical Studies in Mongolia and Adjacent Territories. Proceedings of the Institute of Biology MAS. Ulaanbaatar]. No.24. P.40-45 [in Mongolian with Russian summary].

Bugrovskii V.V. 1990. [Uvs Nuur Hollow as the natural active laboratory] // Informatsionnye Problemy Izucheniya Biosfery [Informational Problems in Study of Biosphere]. Pushchino: Akademiya nauk SSSR. P.5-9 [in Russian].

Clauss M., Lischke A., Botha H. \& Hatt J.-M. 2016. Carcass consumption by domestic rabbits (Oryctolagus cuniculus) // European Journal of Wildlife Research, Vol.62. No.1. P.143-145.

Dorward L.J. 2015. New record of cannibalism in the common hippo, Hippopotamus amphibius (Linnaeus, 1758) // African Journal of Ecology. Vol.53. No.3. P.385-387.
Gleason G.S., Hoffman R.A. \& Wendland J.M. 2005. Beavers, Castor canadensis, feeding on salmon carcasses: opportunistic use of a seasonally superabundant food source // Canadian Field-Naturalist. Vol.119. P.591593.

Romashov V.A. 1958. [Detection of the natural centre of opisthorchosis in Voronezh River basin] // Okhrana Prirody Tsentral'no-Chernozemnoi Polosy. Voronezh. No.1. P.439-441 [in Russian].

Samiya R. 2013. Castor fiber birulai Serebrennikov 1929 // Mongolian Red Book. Ulaanbaatar. P.64-66 [in Mongolian and English].

Saveljev A.P. \& Archimaeva T.P. 2015. [Ecological dynamic of Amniota at seasonal, interannual and long-term changes of water level of Uvs Lake] // Scientific Proceedings of the Institute of General and Experimental Biology MAS, Ulaanbaatar. No.31. P.87-101 [in Russian and English].

Saveljev A.P., Shar S., Scopin A.E., Otgonbaatar M., Soloviev V.A., Putincev N.I. \& Lhamsuren N. 2015. Introduced semiaquatic mammals in the Uvs Nuur Hollow (current distribution and ecological vectors of the naturalization) // Russian Journal of Biological Invasions. Vol.6. No.1. P.37-50.

Stubbe M., Dawaa N., Samjaa R., Stubbe A., Saveljev A.P., Heidecke D., Sumjaa D., Ansorge H., Shar S. \& Ducroz J.-F. 2005. Beaver research in the Uvs Nuur region // Exploration into Biological Resources of Mongolia. Vol.9. P.101-106.

UNESCO 2003. Decisions Adopted by the 27th Session of the World Heritage Committee in 2003. Paris: World Heritage Committee. P.104-105. 